\title{
Evaluation of Parallel Authentic Research-Based Courses in Human Biology on Student Experiences at Stanford University and the University of Gothenburg
}

Jacob Lindh ${ }^{1 \mathrm{a}}$, Claes Annerstedt ${ }^{1 \mathrm{~b}}$, Thor Besier ${ }^{2}$, Gordon O. Matheson ${ }^{3}$, Martin Rydmark ${ }^{4}$

\begin{abstract}
Under a previous grant (2005-08), researchers and teachers at Stanford University (SU) and the University of Gothenburg (GU) co-designed a ten-week interdisciplinary, research-based laboratory course in human biology to be taught online to undergraduate students. Essentials in the subject were taught during the first four weeks of this course. Subsequently, student groups at SU and $G U$ developed their own research questions, conducted live-streamed experiments remotely, processed their unique data with support from multiple interactive resources, cross-cultural collaboration and an interdisciplinary network of expert consultants, and presented original scientific results remotely. Student course-perceptions were evaluated using online questionnaires, reflective blogs, and observations. In student teams from both universities, the course concept clearly improved student abilities to conduct research using laboratory experiments while learning theoretical basics. A comparison of pre-and postcourse scores from student surveys showed that post-course student comfort levels with several research-related tasks increased radically at both universities. All participating staff generally agreed that the methods and tools were valuable in this type of course and should be evaluated at other levels and areas of higher education, and shared in an expanded network of universities.
\end{abstract}

Keywords: Authentic research, laboratory, problem-based learning, blended learning, interdisciplinary, higher education, human biology.

In life science curricula, the integration of physical sciences, mathematics, and computer science has facilitated exciting results in device innovation, medicine, and biological research (National Research Council (NRC), 2003; Caudill et al., 2010). Human biology is a highly researchrelated, interdisciplinary area of life science studies. Several reports and workshops have addressed the increasing quantity of research occurring where human biology intersects other disciplines, which suggests the need for more interdisciplinary, collaborative, and explorative curricula to prepare students for graduate study and future approaches to studying human biology (NRC, 2003; Bologna, 2009; Labov et al., 2010). However, the methods of teaching of modern undergraduate human biology has remained relatively unchanged (NRC, 2003; Labov et

\footnotetext{
${ }^{1 \mathrm{a}}$ Corresponding Author, Lecturer in Human Biology and Doctoral Student, Dep. of Food and Nutrition, and Sport Science, University of Gothenburg, PO Box 300, 40530 Gothenburg, Sweden, jacob.lindh@ gu.se

1b Prof. in Sports Science, Head of Dep., Dep. of Food and Nutrition, and Sport Science, University of Gothenburg, claes.annerstedt@gu.se

${ }^{2}$ Ass. Prof. in Biomechanics, Auckland Bioengineering Institute, Faculty of Engineering, 70 Symonds St., Auckland 1010, New Zeeland, t.besier@auckland.ac.nz

${ }^{3}$ M.D. Prof., Director of Sports Medicine, Stanford University, 341 Galvez St, CA, USA, gord@ stanford.edu

${ }^{4}$ M.D. Prof., Medical Informatics \& Computer Assisted Education, Inst. for Biomedicine, University of Gothenburg, martin.rydmark@mednet.gu.se
} 
al., 2010).

In learning about human biology, students should - among other things-become independent, critical, self-reflective, and aware of research methods. Put differently, students should become "construct-able and research-able"1 (Hultberg et al., 2008; Kjellgren et al., 2008; Annerstedt et al., 2010). Such an outcome requires a pedagogic concept that encourages students to ask questions, construct authentic problems, test hypotheses in laboratory settings against prior scientific knowledge, and communicate and present novel scientific results (Mayers \& Burgess, 2003; NRC, 2003). In fact, several reports underscore the importance of fostering these skills earlier at the undergraduate level, based on reported difficulties with traditionally educated students developing these skills later in their undergraduate studies (Duncan \& Al-Nakeeb, 2006; Kolkhorst et al., 2001). A national survey of biology faculty members $(n=279)$, based on experiences from 534 biology lab classes in the United States, suggests that authentic undergraduate lab research courses in biology should include and be defined by the following components (most important first): experimental design, data collection, data analysis, presentation or publication, hypothesis formation, student-generated questions, and novel questions (Spell et al., 2014). No similar survey report exists in Europe as a comparison.

In education, course modules that involve real-world or authentic research projects are sometimes also known as "research-based", "project-based", "inquiry-based" or "discovery based". International higher educational committees have echoed the importance of more authentic research-based undergraduate involvement in courses to improve education and research (NRC, 2003; American Association for the Advancement of Science (AAAS), 2011; Spell et al., 2014). Several case studies have proven that well-designed curricula can benefit both teaching and existing faculty research, and improve students' authentic research-related skills and abilities (Weaver et al., 2008; Rissing \& Cogan 2009). Though traditional laboratory courses adopting a list of specific lab procedures with anticipated answers to questions still dominate most undergraduate curricula (Buck et al., 2008), more authentic research-based courses have proliferated (Sundberg et al., 2005; Sundberg \& Armstrong, 1993). For most institutions, barriers to shifting curricula include lack of motivation, effort, resources, and time required to make changes (AAAS, 2011). Among researchers, teaching is also often seen as a "burden" that takes time and energy away from productive research (Benvenuto, 2002; Anderson et al., 2011). One solution to this challenge that can benefit researchers and many departments may be to incorporate existing faculty research in the authentic research-based curricula (Hanuaer et al., 2006; Wood, 2009; Baskens, 2011).

This paper describes the outcomes from simultaneous authentic research-based courses at Stanford University and the University of Gothenburg. The outcome from this educational case study was innovative, and in 2015 it still is with regards to content, students, and the combination and use of methods and tools. This makes comparisons with previous and similar case studies difficult.

\section{History - The Research-able Project}

Faculty members at Stanford University (SU) in the United States and the University of Gothenburg (GU) in Sweden collaborated to meet these needs, funded by a Wallenberg Global

\footnotetext{
${ }^{1}$ ConstructAble and ResearchAble are the concepts the RUN team use for students becoming more reflective and critical as well as knowing more about scientific methods (Kjellgren et al., 2008, Annerstedt et al., 2010).

Journal of the Scholarship of Teaching and Learning, Vol. 16, No. 5, October 2016. josotl.indiana.edu 
Learning Network (WGLN) ${ }^{2}$ grant for a joint research and development project in education and technology entitled Remote University Networks (RUN) ${ }^{3}, 2005-2008$. The overall vision of the RUN project was to create a global network of on-demand remote universities and experts in exercise science courses in order to share resources and learn where new pedagogical modes of student-centered and blended learning ${ }^{4}$ were being focused. See Annerstedt et al. 2010 for further details. The first pilot project year, RUN I (2005-06), evaluated two live-streamed remote laboratory experiments conducted by students and remote analysis of the results between students and experts at SU and GU (Garza et al., 2007). The second project year, RUN II (200607), included the first full remote test of the RUN concept in courses at SU and GU (Annerstedt et al., 2010). This paper describes the outcomes from the improved and final project year, RUN III (2007-08). Ethics for the RUN project are described in Annerstedt et al., 2010.

\section{Purpose}

The project purpose was to evaluate the following questions through ethnographical research:

- What impact did the course design have on student and staff expectations, satisfaction, and perceptions at SU and GU?

- What impact did the course design have on undergraduate student research-related skills and abilities at SU and GU?

- Is it possible and valuable to learn the essential basics of biomechanics at the undergraduate level parallel to developing research-related skills and abilities in the same course, compared to learning the essential basics in a traditional course module?

\section{Materials and Methods}

\section{The RUN course}

The RUN project group proposed the study of human movement in exercise science as an interdisciplinary basis for the RUN project and to encourage increased collaboration among departments and universities. Components of human movement in exercise science (injury, rehabilitation, performance, fitness and health) can be described in the context of biomechanics, anatomy, physiology, and technology. The course goals were:

- Knowledge and understanding after the course: The students should 1) understand how human movement is adapted and controlled, with an interdisciplinary focus mainly on biomechanics and on health and performance, 2) know how biomechanical laboratory

\footnotetext{
2 The mission of the WGLN is to help students, from primary grades through graduate school, to achieve better learning outcomes, to support faculty investigators in producing new knowledge for best learning practices, and to develop pedagogical and technical solutions suitable for innovative use in a variety of university and pre-school settings.

${ }^{3}$ RUN project homepage (2008):http://runproject.stanford.edu/index.html

4 "Blended Learning is learning that is facilitated by the effective combination of different modes of delivery, models of teaching and styles of learning, and founded on transparent communication amongst all parties involved with a course" (Heinze and Procter, 2004).

Journal of the Scholarship of Teaching and Learning, Vol. 16, No. 5, October 2016. josotl.indiana.edu 
equipment is used, and understand its limitations, and the student should 3) understand how to collect, analyze, interpret and present biomechanical lab data.

- Skills and abilities after the course: The students should 1) be able to design and conduct movement experiments, 2) be able to use various information and communication technologies to process scientific results, and 3) be able to design posters, write scientific reports and present experimental biomechanical scientific results.

The projects were based on storyboards that progressed groups of students through these phases of learning (Fig. 1). See Annerstedt et al. 2010 for more details about the RUN course and figure 1 below.

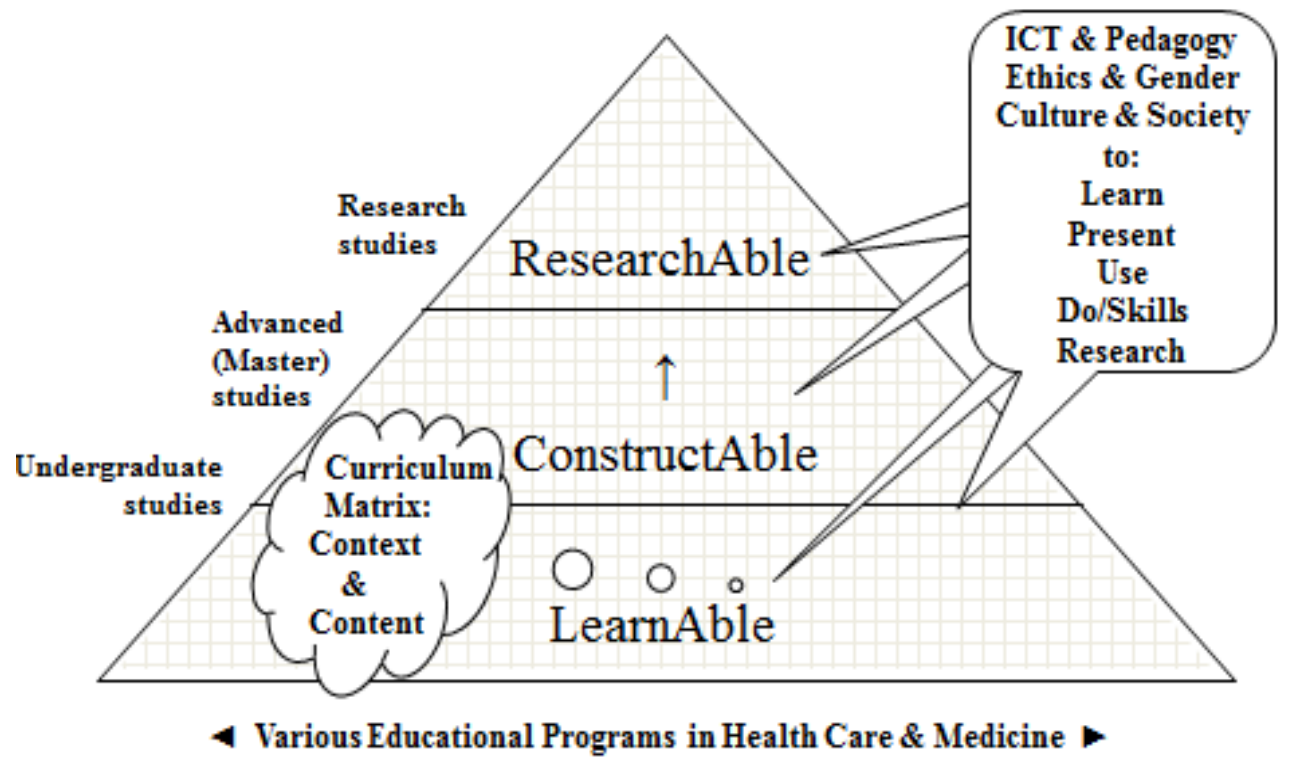

Figure 1. RUN education scaffold. The pyramid illustrates the normal progression from university entrance to research level. The RUN project team believes that all levels and skills in the pyramid should be trained early on in basic courses at the undergraduate level. First, projects required students to actively LEARN key concepts in the subject through lectures and independent work (table 2). Secondly, students began to CONSTRUCT solutions and models to test them. Finally, the group derived data to evaluate their proposed solutions, a key component of RESEARCH.

The innovative aspect of this joint undergraduate blended course, in contrast to a traditional, lecture-based, fact-driven course, was the novel combination of cross-cultural multidisciplinary collaboration, information and communication technology (ICT)-battery use, self-assessment methods, and a deep learning approach that focused on information-seeking processes and problem-based learning in team-based research projects. An overview of the goals and achievements of the RUN collaborative work is described in table 1. 


\section{Participants and Organization}

In spring 2008, the two parallel undergraduate courses enrolled a total of 61 students. SU enrolled 28 (62\% female, 38\% male) second semester Human Biology students, and GU enrolled 33 (48\% female, 52\% male) third semester Physical Education Teacher students. The average age of the students at SU was 21.3 years with a negligible span, and the average age of the students at GU was 26.1 years. The joint teaching staff included three faculty teachers and four teaching assistants (tutors) at $\mathrm{SU}$, and three faculty teachers and three teaching assistants at GU. In addition, both SU and GU students had access to a pool of seven expert consultants from other universities to support student work. The RUN project organization at SU and GU included one project manager (SU-GU project coordinator), two principal investigators each at $\mathrm{SU}$ and $\mathrm{GU}$, one course director each at $\mathrm{SU}$ and GU (main teachers and RUN project executives), one technical expert each at SU and GU (to support SU-GU interactions), and two RUN project evaluators (master students). See acknowledgement and Annerstedt et al., 2010, for more details.

\section{The Learning Process and Tools}

The main topics of basic biomechanics that were taught during the first four weeks of the course were as follows: 1) Basic concepts of biomechanics, 2) biomechanics of bone, articular cartilage, muscles, tendons and ligaments, 3) kinematics and kinetics, and 4) basic gait analysis. Student learning outcomes were tested through written examinations in basic biomechanics (GU week 4 and SU week 5) and a tailor-made self-assessment concept, developed by the RUN-team to cover knowledge gaps during every second week of the course (Annerstedt et al., 2010). During the project-based part of the course (which started during week 4), small student groups developed their own research questions and hypotheses from open-ended storyboards, designed and conducted their own movement experiments in labs, collected and analyzed their unique data, asked questions to tutors and global expert consultants, and reported their findings to the rest of the class and remote groups using presentation software. The SU and GU student groups were formed in a randomized way and they worked together during the entire course. Over the six weeks of the project-based part of the course, students had to manage all available resources to help produce a scholarly work that could lead to further research (see Annerstedt et al., 2010 on pp 110-115 and figure 1 on p. 111 for more details regarding the course design including tools and methods). The timing and topics for all events in the course are described in table 2. Below is an example storyboard with the theme "running economy" to support RUN student groups and their hypothesis development:

Storyboard: Running economy (RE) is formally defined in literature as a runner's steady-state oxygen consumption at submaximal running speed, taking body weight into account [(VO2/kg) at submaximal pace]. Though the definition may seem a bit wordy, you will come to fully understand its meaning and appreciate its relationship to VO2, fatigue, and anaerobic threshold as you proceed with your project. For now, you can think of running economy as a measurement of how efficiently a runner can utilize energy to maintain a certain pace. Compared to individuals with poor RE, runners with good RE are able to run a given speed while using less energy. More than any other measurement, $R E$ is the single best predictor of long distance performance. While both

Journal of the Scholarship of Teaching and Learning, Vol. 16, No. 5, October 2016. josotl.indiana.edu 
physiology and biomechanics affect RE, little is known on how to specifically alter a runner's training regimen to increase an individual's running economy. With the tools available to you, design and run an experiment that investigates the relationship between biomechanical parameters and physiological factors of running economy. Based on your findings, recommend possible methods to improve running economy, decrease fatigue, or reduce injury. Possible projects include analyzing the effects of altered biomechanics on running economy, such as how different running shoes, different running styles, or simulated injury affect RE. Other possible projects include extrapolating how different types of conditioning might alter running economy by comparing athletes from different sports. Relating biomechanics of age and sex to running economy is also an option. This story board is fairly open-ended to allow you the opportunity to be creative in your experiment design. Brainstorm possible research questions. Start by delving into the current literature on running economy to fully understand the topic and see what has already been done. Next, make sure you understand what resources will be available to you and what specific parameters can be measured at your research site. By taking all this into account, you should be able to narrow down your research question (teachers and international experts will be available two hours per group face-to-face or via emeeting on demand, to help facilitate work) so that it is unique, contributes to the current knowledge, and can be completed in the given timeframe. Once you fully define your project, you will submit a project proposal, thoroughly outlining your topic and methodologies of your proposed study. After conducting your research trials, you will have ample time to analyze your data. The course will culminate with a presentation of your findings to your fellow classmates, and remote-students and experts in conferencelike settings. We look forward to discussing your ideas.

\section{Tools for Blended Learning}

The battery of available resources for blended learning and the scientific process included a unified $\mathrm{LMS}^{5}$, homepage, reflective blog, a library of virtual key note lectures, links, animations, storyboards, posters, scientific reports and movement lab recordings, an innovative interactive self-assessment program, and software for asynchronously and synchronously interactive communication, such as wiki, chat, instant message, blog, interactive whiteboards, video-conference and e-meeting software. The students were introduced to all tools before project work. On demand selection of resources for project work was an important way of fostering student independence and self-directed learning ${ }^{6}$. See Annerstedt et al. 2010 for further details.

\footnotetext{
${ }^{5}$ A learning management system (LMS) is a software application or Web-based technology used to plan, implement, and assess a specific learning process. Typically, an LMS provides an instructor with a way to create and deliver content, monitor student participation, and assess student performance. An LMS may also provide students with the ability to use interactive features, such as threaded discussions, video conferencing, and discussion forums (Stone \& Zheng, 2014). The LMS that was shared during the entire RUN course is called Ping Pong (http://pingpong.se)

'.'In its broadest meaning, 'self-directed learning' describes a process by which individuals take the initiative, with or without the assistance of others, in diagnosing their learning needs, formulating learning goals, identify human and material resources for learning, choosing and implement appropriate learning strategies, and evaluating learning outcomes." (Knowles, 1975, p. 18)
}

Journal of the Scholarship of Teaching and Learning, Vol. 16, No. 5, October 2016. josotl.indiana.edu 


\section{Student Assessment and Examination Methods}

The assessment and examination methods listed below were used for student course grading. 1) Content-based examinations: Students at SU and GU were assessed based on the content of mid-term examinations. 2) Reflective blog: SU and GU students kept an individual reflective blog, hosted on an LMS that recorded their experiences and work process throughout the course. 3) Presentation of Storyboard work: Each student project group at SU and GU turned in a 5-8 page scientific report at the end of the course and presented their findings orally to the remote class and experts. Students at both universities also designed posters using PowerPoint following common guidelines used at international conferences. 4) Self-assessment process: Student assessment also involved an element of reflective learning, self-assessment. See Annerstedt et al. 2010 for further details.

\section{Evaluation Methods and Procedure of the RUN III Project}

This project was an exploratory longitudinal case study. RUN II, described by Annerstedt et al. in 2010, was a qualitative study with no questionnaires. This paper focuses mainly on web-based questionnaires with a more quantitative approach, but also on student reflective blogs and personal reflections and observations from RUN staff members. Most questions in the questionnaire were based on a four-six graded Likert scale (Likert, 1932; Chang, 1994). Ordinal data analysis is the most accepted way to analyze Likert scale data (Jaimeson, 2004; Carifio \& Perla, 2008; Sullivan \& Artino, 2013; Ary et al., 2013). Ordinal data results are presented in this paper based on frequency-tables 3 and 4.

Questionnaires: Web-questionnaires were developed and handed out by RUN-faculties. Three SU and GU web-based student evaluation questionnaires were conducted with items of course content and design, comfort level with research-related tasks, ICT-battery use and its values, perspectives on group work and team collaboration, cross-cultural collaboration, the value of developing global skills and abilities in this course, and the impact of the selfassessment concept. This article focuses on the items of course content and design, course impact on student research-related skills and abilities, and whether it was possible to learn basic biomechanics in the RUN course in contrast to more traditional course modules. First, the students conducted one background survey to collect background and baseline data during the first day of the course. 25 students at SU (62\% female, 38\% male) and 33 students at GU (48\% female, $52 \%$ male) conducted the background questionnaire. The response rates were $93 \%$ at SU and $100 \%$ at GU. After each of the six weeks during the course, the students conducted surveys regarding their ICT use and their perceptions of and progression on project work. Finally, the students conducted an exit survey regarding their experiences and impressions of the course. 21 students at SU (62\% female, 38\% male) and 32 students at GU (50\% female, 50\% male) conducted the exit questionnaire on the final day. The response rates were $75 \%$ at SU and $97 \%$ at GU. In all questionnaires, students could also make written comments on most questions.

Reflective blog evaluation: All student written survey comments and student reflective blogs ("individual project diaries") were analyzed thematically, to find similarities and differences in how the students experienced the course (Taylor et al., 2015).

Journal of the Scholarship of Teaching and Learning, Vol. 16, No. 5, October 2016. josotl.indiana.edu 


\section{Results and Comments}

\section{Final Year Course Improvements}

Several obstacles and difficulties were identified during the RUN II project (Annerstedt et al., 2010) that were changed before the RUN III courses started at SU and GU in 2008:

- The course concept was explained by experts, but many students, especially at GU, still did not understand the purpose of all the new tools and methods implemented during the course and how to use them effectively. A detailed study guide was developed only at GU to clarify these and to facilitate student work. SU did not find this necessary, since they already had similar documents, and due to some course differences explained in item three below.

- Several technical difficulties for students using audiovisual communication tools (AVC) were identified. Instruction manuals for AVC use with step-by-step protocols and best practices were developed; one IT staff expert at GU was recruited to support the interactions; facilities for $\mathrm{SU}$ and $\mathrm{GU}$ group interactions and laptops were better prepared; and more hands-on lecture time with IT staff experts on AVC usage was built into the RUN III courses.

- The SU and GU courses during RUN III were directed more separately at SU and GU, and all interactions were scheduled with the teaching staff participating, mainly due to differences in educational systems and cultures, administrative routines and how courses are run, differences in academic student backgrounds, large time zone differences (nine hours), and differences in student out-of-class life management. Six lectures presented by international experts were live-streamed over web-video from SU or GU to all students simultaneously (one remote and one physical class). Eight SU and GU interactions were conducted during the course. Interactions were held once or twice every week. The topics and timing of these interactions are illustrated in table 2 (yellowmarked sections).

- The essentials in biomechanics were taught simultaneously with project work at GU during RUN II, which caused organizational problems for GU students in organizing their learning (Annerstedt et al., 2010). Because of this, the RUN III courses at SU and GU were divided into, first, a theoretical part (four weeks) and a second, project-based RUN course part (six weeks). Some lectures were also held during the project-based part, but the purpose of these lectures was mainly to help students with their projects (lab equipment, analyze results, a few more advanced lectures with biomechanical lab research and how to present scientific results). An interactive self-assessment concept was implemented and tested for the first time to enhance learning of the key concepts in biomechanics. Self-assessments were conducted every second week (with actual course content) for students to check their knowledge and for teachers to identify weaknesses to better support individual student needs throughout the course. The RUN III courses ran over ten weeks, instead of five weeks, to allow all participants more time to become familiar with the concept, each other, and to deal with any problems that could occur.

Journal of the Scholarship of Teaching and Learning, Vol. 16, No. 5, October 2016. 
The students studied other courses in parallel during RUN III. The RUN course credits were the same and the study load was "similar" for SU and GU students during RUN II and III. Table 1 describes the achievements from the RUN III collaborative work between SU and GU to establish the final and improved course concept in 2008. Table 2 describes the final and improved aligned parallel SU and GU syllabus of the RUN III courses.

\section{Table 1: Overview of the goals and achievements of the RUN III collaborative work:}

\begin{tabular}{|c|c|}
\hline Goals of Grant & Achievements \\
\hline $\begin{array}{l}\text { Design joint course in exercise } \\
\text { science }\end{array}$ & $\begin{array}{l}\text { - Gothenburg: "Biomechanics and Human Performance" } \\
\text { - Stanford: "Functional Anatomy of Exercise" } \\
\text { - Courses have similar content goals and similar curricula to allow } \\
\text { for differences in cultural context (e.g., no letter grades at } \\
\text { Gothenburg/letter grades at Stanford) } \\
\text { - Lectures, experiments, and content shared as appropriate } \\
\text { - } \quad \text { Group work \& cooperation between groups at different sites } \\
\text { - E-meeting software used for real-time communication }\end{array}$ \\
\hline $\begin{array}{l}\text { Design storyboards for } \\
\text { interdisciplinary learning } \\
\text { models }\end{array}$ & - 1) Knee, 2) Spine, 3) Ankle, and 4) Running economy \\
\hline $\begin{array}{l}\text { Develop cooperation between } \\
\text { Gothenburg and Stanford faculty }\end{array}$ & $\begin{array}{l}\text { - } \quad \text { Bimonthly web conferences } \\
\text { - Three exchange visits } \\
\text { - Joint decisions on curricula }\end{array}$ \\
\hline $\begin{array}{l}\text { Develop cooperation between } \\
\text { Gothenburg and Stanford } \\
\text { Student Tutors/Mentors }\end{array}$ & $\begin{array}{l}\text { - } \quad \text { Two exchange visits for tutors } \\
\text { - Web conferences to discuss goals } \\
\text { - } \quad \text { Cooperation on student guidance }\end{array}$ \\
\hline Develop new technologies & $\begin{array}{ll}\text { - } & \text { Developed project website } \\
\text { - } & \text { Adapted Ping-Pong (LMS) for use with course } \\
\text { - } & \text { Web-hosted lab experiments } \\
\text { - } & \text { Standardized lectures \& guided group interactions/discussions } \\
\end{array}$ \\
\hline $\begin{array}{l}\text { Developed new pedagogical } \\
\text { model }\end{array}$ & $\begin{array}{ll} & \text { Cooperative learning } \\
\text { - } & \text { Student self-assessment } \\
\text { - } & \text { Scaffold learning matrix } \\
\text { - } & \text { Development of research skills } \\
\end{array}$ \\
\hline Expanded faculty involvement & - Recruited faculty consultants and keynote lecturers \\
\hline Pedagogical evaluation & $\begin{array}{l}\text { - Assessment of SU and GU student satisfaction and feasibility of } \\
\text { course design and implementation using surveys and ethnographic } \\
\text { methods }\end{array}$ \\
\hline $\begin{array}{l}\text { Evaluation of course content and } \\
\text { implementation }\end{array}$ & $\begin{array}{ll} & \text { Standardized assessment of knowledge } \\
\text { - } & \text { Student satisfaction surveys and interviews } \\
\end{array}$ \\
\hline Student-generated research & $\begin{array}{l}\text { Use student-generated research progress and presentations to } \\
\text { evaluate the effectiveness of this pedagogical approach in teaching } \\
\text { interdisciplinary biological \& engineering curricula }\end{array}$ \\
\hline $\begin{array}{l}\text { Publications and proceedings at } \\
\text { international ICT and e-health } \\
\text { conferences }\end{array}$ & $\begin{array}{l}\text { - } 1^{\text {st }} \text { conference: Paper and poster: Medicine Meets Virtual Reality in } \\
\text { San Diego, USA (Garza et al., 2007) } \\
\text { - } 2^{\text {nd }} \text { conference: Proceeding and Keynote lecture: Vitalis } \\
\text { Conference (e-health) in Gothenburg, Sweden (2007) }\end{array}$ \\
\hline
\end{tabular}

Journal of the Scholarship of Teaching and Learning, Vol. 16, No. 5, October 2016. josotl.indiana.edu 
Lindh, Annerstedt, Besier, Matheson, and Rydmark

Table 2: The aligned six-week parallel SU and GU syllabus of the project-based part of the course. Grey areas represent scheduled SU-GU interactions.

\begin{tabular}{|c|c|c|c|c|c|c|}
\hline Date & Day & $\begin{array}{l}\text { University of Gothenburg (GU) } \\
\text { Lecture }\end{array}$ & $\begin{array}{l}\text { Stanford University (SU) } \\
\text { Lecture }\end{array}$ & Activity & Notes & $\begin{array}{c}\text { SU TA } \\
\text { Meeting }\end{array}$ \\
\hline 4-1 & $\mathrm{T}$ & \multicolumn{2}{|c|}{ Class Intro (Teacher 1 and 2) (SU: 8:00 - 8:40am) } & $\begin{array}{l}\text { Cultural Interaction } \\
\text { (SU 8:45-9:15am) }\end{array}$ & $\begin{array}{l}\text { GU: Anatomy Homework Task } \\
\text { SU: Announce Groups }\end{array}$ & \multirow[t]{4}{*}{. } \\
\hline $4-2$ & $\mathrm{~W}$ & - & - & - & & \\
\hline $4-3$ & Th & Biomechanics I (Teacher 3) & $\begin{array}{l}\text { Biomechanics I: Forces, Vectors, } \\
\text { Moment Arms (Teacher 4) }\end{array}$ & SU: Assessment Blog & & \\
\hline $4-4$ & $\mathrm{~F}$ & Kinesiology I (Teacher 1) & - & - & & \\
\hline $4-7$ & $\bar{M}$ & Group 1-2: ICT I (Teacher 3) & - & 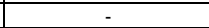 & & \multirow{5}{*}{$\begin{array}{l}\text { Marratech } \\
\text { Demo }\end{array}$} \\
\hline $4-8$ & $\mathrm{~T}$ & Kinesiology II (Teacher 1) & Anatomy Review (Teacher 2) & $\begin{array}{c}\text { Biomechanics I } \\
\text { Interaction } \\
\text { (SU: } 8: 10-8: 40 \mathrm{~m}) \\
\end{array}$ & $\begin{array}{l}\text { GU: MT \& PP Demo } \\
\text { SU: TA Meetings Begin }\end{array}$ & \\
\hline $4-9$ & $\mathrm{~W}$ & Group 1-2: ICT II (Teacher 3) & - & - & GU: Group Lab & \\
\hline $4-10$ & Th & Storyboard Groups (Teacher 1 and 3) & $\begin{array}{c}\text { Free Body Diagrams (Teacher 2,4 } \\
\text { and 7) }\end{array}$ & SU: Assessment Blog & $\begin{array}{l}\text { GU: Questions before self-assessment } \\
\text { SU: Handout Project Proposal/ Lit Review }\end{array}$ & \\
\hline $4-11$ & $\mathrm{~F}$ & Group A+B:Self Assessment I (Teacher 3) & - & - & SU: Lab Principles available on-line & \\
\hline $4-14$ & $\mathrm{M}$ & Biomechanics II (Teacher 5) & - & - & GU: Storyboard Group Assessments & \multirow{5}{*}{ Project Intro } \\
\hline $4-15$ & $\mathrm{~T}$ & \multicolumn{2}{|c|}{ Expert Keynote I - Gait Analysis (Teacher 8) (SU: 8:00 - 8:40am) } & $\begin{array}{c}\text { FBD Interaction } \\
(S U: 8: 45-9: 15 a m)\end{array}$ & $\begin{array}{l}\text { GU: Students work through QTM HW (Teacher } 3 \\
\text { Available) }\end{array}$ & \\
\hline $4-16$ & W & Lab Principles (Teacher 1,5 and 6) & - & - & GU: QTM \& Excel & \\
\hline $4-17$ & Th & Storyboard Groups (Teacher 1 and 3) & Lab Principles in HPL (Teacher 4) & SU: Assessment Blog & $\begin{array}{l}\text { GU: Question Session before self assessment } \\
\text { SU: Lab Time Sign Up }\end{array}$ & \\
\hline $4-18$ & $\mathrm{~F}$ & Self Assessment 2 (Teacher 3) & - & - & & \\
\hline $4-21$ & M & $\begin{array}{c}\text { Question Session before Examination } \\
\text { (Teacher 1,3 and 6) }\end{array}$ & - & - & $\begin{array}{l}\text { GU: Group Assessment } \\
\text { SU: Project Proposal DUE }\end{array}$ & \multirow{5}{*}{$\begin{array}{l}\text { Project } \\
\text { Proposal } \\
\text { Feedback }\end{array}$} \\
\hline $4-22$ & $\mathrm{~T}$ & $\begin{array}{c}\text { Examination - Biomechanics \& Human } \\
\text { Performance }\end{array}$ & Keynote (Teacher 7) & $\begin{array}{c}\text { Project Proposal/ } \\
\text { Experiment } \\
\text { Presentation } \\
\text { (SU: } 8: 10-8: 40 \mathrm{am})\end{array}$ & GU: Proposal Discussion \& Presentation & \\
\hline $4-23$ & W & Proposal Group Work & - & - & & \\
\hline $4-24$ & Th & - & $\begin{array}{c}\text { Biomechanics II: Material Properties } \\
\text { (Teacher 4) }\end{array}$ & SU: Assessment Blog & GU: Deadline for Preproposals & \\
\hline $4-25$ & $\mathrm{~F}$ & - & - & - & GU: Proposals DUE & \\
\hline $4-28$ & M & $\begin{array}{c}\begin{array}{c}\text { Experiments at Lundberg Lab (Teacher 3,5 } \\
\text { and 6) }\end{array} \\
\end{array}$ & - & - & & \multirow{5}{*}{ Experiments } \\
\hline $4-29$ & $\mathrm{~T}$ & \multicolumn{2}{|c|}{ Biomechanics of Skiing (Teacher 9) (SU: 8:00 - 8:45am) } & $\begin{array}{c}\text { Biomechanics II } \\
\text { Interaction } \\
\text { (SU: 8:45 - 9:15am) } \\
\end{array}$ & & \\
\hline $4-30$ & W & - & - & - & & \\
\hline $5-1$ & Th & - & Bone (Teacher 2) & SU: Assessment Blog & & \\
\hline $5-2$ & $\mathrm{~F}$ & $\begin{array}{l}\text { Feedback on Results of Experiment } \\
\text { (Teacher } 3,5 \text { and } 6)\end{array}$ & - & - & & \\
\hline $5-5$ & $\mathrm{M}$ & - & - & - & & \multirow{5}{*}{$\begin{array}{c}\text { Bone, } \\
\text { Tendon, \& } \\
\text { Ligament } \\
\text { Aspects of } \\
\text { Experiments }\end{array}$} \\
\hline $5-6$ & $\mathrm{~T}$ & Interaction Only (Teacher 3 and 5) & Tendon \& Ligament (Teacher 4) & $\begin{array}{c}\text { Lab Reflection } \\
\text { Interaction } \\
\text { (SU: } 8: 10-8: 40 a m \text { ) }\end{array}$ & SU: All Experiments Completed & \\
\hline $5-7$ & W & - & - & - & & \\
\hline $5-8$ & Th & - & Midterm & - & SU: Midterm Covers through Tendon \& Ligament & \\
\hline $5-9$ & $\mathrm{~F}$ & - & - & - & & \\
\hline $5-12$ & $\mathrm{M}$ & - & - & - & GU: Possibility to Conduct New Experiments & \multirow{10}{*}{\begin{tabular}{|c} 
Cartilage and \\
Injury \\
Aspects of \\
Experiment
\end{tabular}} \\
\hline $5-13$ & $\mathrm{~T}$ & $\begin{array}{l}\text { Academic Attitude - LearnAble Project } \\
(\text { Teacher 10) }\end{array}$ & Muscle (Teacher 4) & - & $\begin{array}{l}\text { GU: No Interaction } \\
\text { SU: TA Meeting via MT, No GU/SU Interaction }\end{array}$ & \\
\hline $5-14$ & W & $\begin{array}{c}\text { Guidelines - Posters \& Scientific Reports } \\
\text { (Teacher 1) }\end{array}$ & - & - & & \\
\hline $5-15$ & Th & \multicolumn{2}{|c|}{ Expert Keynote II - Mechanisms of Injury - Knee \& Ankle (Teacher 11) } & SU: Assessment Blog & & \\
\hline $5-16$ & $\mathrm{~F}$ & - & - & - & & \\
\hline $5-19$ & $\mathrm{M}$ & - & - & - & & \\
\hline $5-20$ & $\mathrm{~T}$ & - & $\begin{array}{c}\text { Expert Keynote III - Cartilage } \\
\text { (Teacher 12) (SU: 8:45 - 9:30am) }\end{array}$ & $\begin{array}{l}\text { Results I: SU Present } \\
\text { (SU: 8:10-8:40am) }\end{array}$ & GU: Final Discussion on Progress & \\
\hline $5-21$ & $\mathrm{~W}$ & - & - & - & & \\
\hline $5-22$ & Th & & $\begin{array}{c}\text { Expert Keynote IV - Tissue Injury \& } \\
\text { Healing (Teacher 13) (SU: 8:00 - } \\
\text { 8:40am) } \\
\end{array}$ & SU: Assessment Blog & & \\
\hline $5-23$ & $\mathrm{~F}$ & - & - & - & & \\
\hline $5-26$ & M & \begin{tabular}{|c|} 
Expert Consultation via Marratech (Teacher \\
11)
\end{tabular} & - & - & & \multirow{5}{*}{$\begin{array}{l}\text { Presentation } \\
\text { Prep }\end{array}$} \\
\hline $5-27$ & $\mathrm{~T}$ & \multicolumn{2}{|c|}{ Mechanisms of Sport Injury (Teacher 2) (SU:8:00 - 8:40am) } & $\begin{array}{l}\text { Results II: GU Present } \\
\text { (SU: 8:45-9:15am) }\end{array}$ & & \\
\hline $5-28$ & W & - & - & - & & \\
\hline $5-29$ & Th & - & Final Exam & - & SU: Final Exam covers ALL Material & \\
\hline $5-30$ & $\mathrm{~F}$ & - & - & - & & \\
\hline $6-2$ & $\mathrm{M}$ & Deadline of Posters \& Scientific Reports & - & - & & \multirow{5}{*}{$\begin{array}{c}\text { Final } \\
\text { Presentation } \\
\text { Prep }\end{array}$} \\
\hline $6-3$ & $\mathrm{~T}$ & \multicolumn{2}{|c|}{ Interaction Only - Presentation \& Peer Review (SU: 8:10 - 9:10am) } & $\begin{array}{c}\text { Peer Review } \\
\text { (SU: 8:10-9:10am) }\end{array}$ & SU/GU: 1 Hour Interaction Time for Peer Review & \\
\hline $6-4$ & W & - & - & - & & \\
\hline $6-5$ & Th & $\begin{array}{c}\text { Oral Presentations of Posters \& Projects } \\
\text { (Teacher } 3,5 \text { and } 6 \text { ) }\end{array}$ & & - & & \\
\hline $6-6$ & $\mathrm{~F}$ & Grading of Projects & - & - & & \\
\hline $6-9$ & $\bar{M}$ & - & Final Presentations - Groups $1 \& 2$ & - & SU: Presentation Times TBA & \multirow{3}{*}{ - } \\
\hline $6-10$ & $T$ & - & & - & & \\
\hline $6-11$ & W & - & Final Presentations - Groups $3 \& 4$ & - & SU: Presentation Times TBA & \\
\hline
\end{tabular}

Journal of the Scholarship of Teaching and Learning, Vol. 16, No. 5, October 2016.

josotl.indiana.edu 


\section{Pre-Course Results}

RUN Course Election: The most frequently given reasons for students electing the RUN course at SU was interest in sports medicine (48\%) and the importance of the course to their area of concentration (24\%). At GU, the course was an obligatory part of their educational program.

Student Pre-Course Research Experience: SU and GU students were asked about what type of research experience they had conducting research before the course started. The students were able to choose one or more suitable options. Their pre-course research experience was as follows: No experience (SU 12\%, GU 24\%), literature review (SU 80\%, GU 67\%), experimental/ hypothesis testing (SU 60\%, GU 18\%), working in a research laboratory (SU, $64 \%$, GU 3\%), qualitative/case studies (SU 20\%, GU 33\%), and other research (SU 8\%, GU $15 \%)$.

The students were also asked to answer the following question before the course; "Please rank your comfort level with the following research related tasks": Focusing on a research topic, conducting a literature review, developing a hypothesis, designing an experiment and analyzing experimental results. Comfort levels with the following research-related tasks were evaluated based on a six-item graded Likert scale, ranging from (1) Not comfortable at all to (6) Very comfortable. The average SU student felt comfortable with these research-related tasks, while the average GU student felt somewhat comfortable; Likert $1-6$; SU Mdn (Median) and IQR (Inter-quartile range; $\left.\mathrm{q}_{1}-\mathrm{q}_{3}=\mathrm{r}\right) 5(4-5=1)-\mathrm{GU}$ Mdn and IQR $3(2-4=2)=\mathrm{SU}+2$. The average comfort level with all research-related tasks was found to be much higher at SU before the course. These results are presented in detail in table 3 and compared with the post-course results.

\section{Post-Course Results}

Course Evaluation: The students were asked how the course met their expectations. Most SU students were very positive about the course and offered the following typical comments:

The course gave me the freedom to choose a topic of my liking and provided me with all the resources to conduct a rigorous investigation.

It was a fun, exciting, and intriguing course covering a variety of disciplines. I thought the project really made the students do some serious planning and execution of fun, real-world stuff.

Overall, very well. I enjoyed the research project and how the project was much more the focus than the lectures. However, the interactions with the Swedish students did not seem as well integrated into the course as I had expected.

A typical comment from GU students was that they did not think the course was relevant for them as teachers, that the focus was geared too much toward medicine, and that the RUN course content should be better adapted for Physical Education students. However, many of the students enjoyed working with problem-based learning, new assessment methods, and ICT tools.

Journal of the Scholarship of Teaching and Learning, Vol. 16, No. 5, October 2016.

josotl.indiana.edu 
The students were asked to suggest two improvements for the course. The most common answers from both sets of students were related to the interactions between SU and GU students. Most SU students responded that they felt positive about the interactions, but suggested some improvements. Two SU students offered the following comments:

Better integrate the interactions with the Swedish students into the class. This could be done by having groups always talk to the same Swedish groups, conferencing more frequently, and/or being more involved in the development of each other's projects (i.e. conduct peer reviews of research proposals, etc.).The project timelines would need to line up more closely (for example, they were presenting their projects before we had even gotten our data back).

The 8 a.m. time was a little hard. It would have been fine if the interactions with the Swedish colleagues always happened, but they sometimes did not. Perhaps to give us a little more direction with the projects.

This comment from one GU student is representative of many GU student responses:

Make the interactions mandatory and longer with common projects for $G U$ and $S U$ students to make the interactions more meaningful. Make the course more adaptable to our profession as future teachers to improve motivation.

Student Post-Course Research Experience (table 3): The students were asked to answer the same question after the course; "Please rank your comfort level with the following researchrelated tasks" (table 3). Unfortunately only post-course data exists for five of the eight research abilities and skills in table 3. The evaluation in table 3 was based on the same six-item graded Likert scale as before the course, ranging from (1) Not comfortable to (6) Very comfortable.

Table 3: Pre- and post-course questionnaire percentiles and frequency values; median, interquartile range $\left(\mathrm{q}_{1}-\mathrm{q}_{3}=\mathrm{r}\right)$ and pre- and post-course median difference for the following question: "Please rank your comfort level with these research-related tasks".

\begin{tabular}{|c|c|c|c|c|c|c|c|c|c|c|}
\hline $\begin{array}{l}\text { Research } \\
\text { abilities and } \\
\text { skills }\end{array}$ & Univ. & \# Stud. & Not $1^{1}$ & 2 & 3 & 4 & 5 & Very 6 & $\begin{array}{l}\text { Median and } \\
\text { IQR }^{2}\end{array}$ & $\begin{array}{l}\text { Pre- and } \\
\text { post-course } \\
\text { difference }^{3}\end{array}$ \\
\hline \multirow{4}{*}{$\begin{array}{l}\text { Focusing on a } \\
\text { research topic }\end{array}$} & $\mathrm{SU}_{\mathrm{pre}}{ }^{4}$ & $n=25$ & $0 \%(0)$ & $0 \%(0)$ & $12 \%(3)$ & $12 \%(3)$ & $56 \%(14)^{*}$ & $20 \%(5)$ & $5(4.5-5=0.5)$ & \multirow{2}{*}{$5-6=1$} \\
\hline & SU post & $n=21$ & $0 \%(0)$ & $0 \%(0)$ & $0 \%(0)$ & $5 \%(1)$ & $38 \%(8)$ & $57 \%(12)$ & $6(5-6=1)$ & \\
\hline & GU pre & $n=33$ & $3 \%(1)$ & $15 \%(5)$ & $27 \%(9)$ & $27 \%(9)$ & $24 \%(8)$ & $3 \%(1)$ & $4(3-5=2)$ & \multirow{2}{*}{$4-5=1$} \\
\hline & GU post & $n=32$ & $0 \%(0)$ & $3 \%(1)$ & $3 \%(1)$ & $28 \%(9)$ & $47 \%(15)$ & $19 \%(6)$ & $5(4-5=1)$ & \\
\hline \multirow{4}{*}{$\begin{array}{l}\text { Conducting a } \\
\text { literature } \\
\text { review }\end{array}$} & SU pre & $n=25$ & $0 \%(0)$ & $0 \%(0)$ & $16 \%(4)$ & $12 \%(3)$ & $48 \%(12)$ & $24 \%(6)$ & $5(4-5.5=1.5)$ & \multirow{2}{*}{$5-6=1$} \\
\hline & SU post & $n=21$ & $0 \%(0)$ & $0 \%(0)$ & $0 \%(0)$ & $10 \%(2)$ & $24 \%(5)$ & $67 \%(14)$ & $6(5-6=1)$ & \\
\hline & GU pre & $n=33$ & $3 \%(1)$ & $12 \%(4)$ & $30 \%(10)$ & $27 \%(9)$ & $18 \%(6)$ & $9 \%(3)$ & $4(3-5=2)$ & \multirow{2}{*}{$4-5=1$} \\
\hline & GU post & $n=32$ & $0 \%(0)$ & $3 \%(1)$ & $3 \%(1)$ & $31 \%(10)$ & $47 \%(15)$ & $16 \%(5)$ & $5(4-5=1)$ & \\
\hline
\end{tabular}

${ }^{1}$ Likert scale $=1$ (not comfortable) to 6 (very comfortable). ${ }^{2}$ Median and interquartile range $\left(\mathrm{q}_{1}-\mathrm{q}_{3}=\mathrm{r}\right)$.

${ }^{3}$ Pre- and post-course median difference. ${ }^{4}$ Light grey areas $=\mathrm{SU}$ values. $*$ Bolded $=$ Median Likert values.

Journal of the Scholarship of Teaching and Learning, Vol. 16, No. 5, October 2016. josotl.indiana.edu 
Lindh, Annerstedt, Besier, Matheson, and Rydmark

Continuation of table 3 .

\begin{tabular}{|c|c|c|c|c|c|c|c|c|c|c|}
\hline $\begin{array}{l}\text { Research } \\
\text { abilities and } \\
\text { skills }\end{array}$ & Univ. & \# Stud. & Not $1^{1}$ & 2 & 3 & 4 & 5 & Very 6 & $\begin{array}{l}\text { Median and } \\
\mathrm{IQR}^{2}\end{array}$ & $\begin{array}{l}\text { Pre- and } \\
\text { post-course } \\
\text { difference }\end{array}$ \\
\hline \multirow{4}{*}{$\begin{array}{l}\text { Developing a } \\
\text { hypothesis }\end{array}$} & SU pre & $\mathrm{n}=25$ & $4 \%(1)$ & $4 \%(1)$ & $12 \%(3)$ & $12 \%(3)$ & $44 \%(11)$ & $24 \%(6)$ & $5(4-5.5=1.5)$ & \multirow{2}{*}{$5-6=1$} \\
\hline & SU post & $\mathrm{n}=21$ & $0 \%(0)$ & $0 \%(0)$ & $0 \%(0)$ & $0 \%(0)$ & $29 \%(6)$ & $71 \%$ & $6(5-6=1)$ & \\
\hline & GU pre & $\mathrm{n}=33$ & $3 \%(1)$ & $24 \%(8)$ & $24 \%(8)$ & $21 \%(7)$ & $24 \%(8)$ & $3 \%(1)$ & $3(2-5=3)$ & \multirow{2}{*}{$3-5=2$} \\
\hline & GU post & $\mathrm{n}=32$ & $0 \%(0)$ & $9 \%(3)$ & $3 \%(1)$ & $25 \%(8)$ & $47 \%(15)$ & $16 \%(5)$ & $5(4-5=1)$ & \\
\hline \multirow{4}{*}{$\begin{array}{l}\text { Designing an } \\
\text { experiment }\end{array}$} & $\mathrm{SU}_{\mathrm{pre}}{ }^{4}$ & $\mathrm{n}=25$ & $0 \%(0)$ & $4 \%(1)$ & $24 \%(6)$ & $24 \%(6)^{*}$ & $40 \%(10)$ & $8 \%(2)$ & $4(3-5=2)$ & \multirow{2}{*}{$4-5=1$} \\
\hline & SU post & $\mathrm{n}=21$ & $0 \%(0)$ & $0 \%(0)$ & $0 \%(0)$ & $19 \%(4)$ & $33 \%(7)$ & $48 \%(10)$ & $5(5-6=1)$ & \\
\hline & GU pre & $\mathrm{n}=33$ & $15 \%(5)$ & $39 \%(13)$ & $12 \%(4)$ & $12 \%(4)$ & $21 \%(7)$ & $0 \%(0)$ & $2(2-4=2)$ & \multirow{2}{*}{$2-4=2$} \\
\hline & GU post & $\mathrm{n}=32$ & $0 \%(0)$ & $6 \%(2)$ & $13 \%(4)$ & $34 \%(11)$ & $41 \%(13)$ & $6 \%(2)$ & $4(4-5=1)$ & \\
\hline \multirow{4}{*}{$\begin{array}{l}\text { Analyzing } \\
\text { experimental } \\
\text { results }\end{array}$} & SU pre & $\mathrm{n}=25$ & $0 \%(0)$ & $20 \%(5)$ & $20 \%(5)$ & $16 \%(4)$ & $20 \%(5)$ & $24 \%(6)$ & $4(3-5.5=2.5)$ & \multirow{2}{*}{$4-5=1$} \\
\hline & SU post & $\mathrm{n}=21$ & $0 \%(0)$ & $0 \%(0)$ & $5 \%(1)$ & $33 \%(7)$ & $33 \%(7)$ & $29 \%(6)$ & $5(4-6=2)$ & \\
\hline & GU pre & $\mathrm{n}=33$ & $3 \%(1)$ & $24 \%(8)$ & $30 \%(10)$ & $30 \%(10)$ & $9 \%(3)$ & $3 \%(1)$ & $3(2-4=2)$ & \multirow{2}{*}{$3-4=1$} \\
\hline & GU post & $\mathrm{n}=32$ & $3 \%(1)$ & $13 \%(4)$ & $13 \%(4)$ & $25 \%(8)$ & $38 \%(12)$ & $9 \%(3)$ & $4(3-5=2)$ & \\
\hline \multirow{2}{*}{$\begin{array}{l}\text { Conducting } \\
\text { the experiment } \\
\dagger\end{array}$} & SU post & $\mathrm{n}=21$ & $0 \%(0)$ & $0 \%(0)$ & $5 \%(1)$ & $10 \%(2)$ & $38 \%(8)$ & $48 \%(10)$ & $5(5-6=1)$ & $5 \dagger$ \\
\hline & GU post & $\mathrm{n}=32$ & $0 \%(0)$ & $3 \%(1)$ & $16 \%(5)$ & $28 \%(9)$ & $34 \%$ & $19 \%(6)$ & $5(4-5=1)$ & $5 \dagger$ \\
\hline \multirow{2}{*}{$\begin{array}{l}\text { Learning how } \\
\text { to use/inter- } \\
\text { pret data } \dagger\end{array}$} & SU post & $\mathrm{n}=21$ & $0 \%(0)$ & $0 \%(0)$ & $0 \%(0)$ & $33 \%$ (7) & $33 \%$ (7) & $33 \%(7)$ & $5(4-6=2)$ & $5 \dagger$ \\
\hline & GU post & $\mathrm{n}=32$ & $3 \%(1)$ & $16 \%(5)$ & $9 \%(3)$ & $31 \%(10)$ & $28 \%(9)$ & $13 \%(4)$ & $4(3-5=2)$ & $4 \dagger$ \\
\hline \multirow{2}{*}{$\begin{array}{l}\text { Presenting } \\
\text { your } \\
\text { experiment } \dagger\end{array}$} & SU post & $\mathrm{n}=21$ & $0 \%(0)$ & $0 \%(0)$ & $0 \%(0)$ & $19 \%(4)$ & $33 \%$ (7) & $48 \%(10)$ & $5(5-6=1)$ & $5 \dagger$ \\
\hline & GU post & $n=32$ & $3 \%(1)$ & $3 \%(1)$ & $13 \%(4)$ & $34 \%$ & $31 \%(10)$ & $16 \%(5)$ & $4(4-5=1)$ & $4 \dagger$ \\
\hline \multirow{3}{*}{$\begin{array}{l}\text { Total average } \\
\text { values }\end{array}$} & SU pre & $\mathrm{n}=25$ & $1 \%(1)$ & $6 \%(7)$ & $17 \%(21)$ & $15 \%(19)$ & $42 \%(52)$ & $20 \%(25)$ & $5(4-5=1)$ & \multirow{2}{*}{$5-6=1$} \\
\hline & $\mathrm{SU}_{\text {post }}{ }^{5}$ & $n=21$ & $0 \%(0)$ & $0 \%(0)$ & $1 \%(1)$ & $13 \%(14)$ & $31 \%(33)$ & $54 \%(57)$ & $6(5-6=1)$ & \\
\hline & $\mathrm{SU}_{\text {post }}{ }^{6}$ & $\mathrm{n}=21$ & $0 \%(0)$ & $0 \%(0)$ & $1 \%(2)$ & $16 \%$ (27) & $33 \%(55)$ & $50 \%(84)$ & $5.5(5-6=1)$ & 5.5 \\
\hline \multirow{3}{*}{$\begin{array}{l}\text { Total average } \\
\text { values }\end{array}$} & GU pre & $\mathrm{n}=33$ & $5 \%(9)$ & $23 \%(38)$ & $25 \%$ & $24 \%(39)$ & $19 \%(32)$ & $4 \%(6)$ & $3(2-4=2)$ & \multirow{2}{*}{$3-5=2$} \\
\hline & $\mathrm{GU}_{\text {post }}{ }^{5}$ & $\mathrm{n}=32$ & $1 \%(1)$ & $7 \%(11)$ & $7 \%(11)$ & $29 \%(46)$ & $44 \%(70)$ & $13 \%(21)$ & $5(4-5=1)$ & \\
\hline & $G_{\text {post }}{ }^{6}$ & $\mathrm{n}=32$ & $1 \%(3)$ & $7 \%(18)$ & $9 \%(23)$ & $30 \%(76)$ & $39 \%(100)$ & $14 \%(36)$ & $5(4-5=1)$ & 5 \\
\hline
\end{tabular}

${ }^{1}$ Likert scale $=1$ (not comfortable) to 6 (very comfortable). ${ }^{2}$ Median and interquartile range $\left(\mathrm{q}_{1}-\mathrm{q}_{3}=\mathrm{r}\right) .{ }^{3}$ Pre- and post-course median difference. ${ }^{4}$ Light grey areas $=\mathrm{SU}$ values. ${ }^{5}$ Average of the same five research skills as averaged for pre-course skills. ${ }^{6}$ Averge of all eight post-course skills. ${ }^{*}$ Bolded $=$ Median Likert values. $\dagger$ Post-course data only.

Post-Course Impact (table 3): The average SU student felt very comfortable with all eight research-related tasks that were evaluated after the course, while the average GU student felt comfortable; SU Mdn and IQR $5.5(5-6=1)-$ GU Mdn and IQR $5(4-5=1)=\mathrm{SU}+0.5$. The average post-course comfort level with these research-related tasks was found to be much higher at SU. $83 \%$ of the SU students and $53 \%$ of the GU students felt comfortable to very comfortable (Likert 5 - 6) with these tasks after the course.

Pre- and Post-Course Comparison (table 3): Compared to the scores gathered prior to the course, the average student comfort level with these five tasks increased radically at SU Journal of the Scholarship of Teaching and Learning, Vol. 16, No. 5, October 2016. josotl.indiana.edu 
(Mdn pre- and post-course difference 5-6 =1) and at GU (Mdn pre- and post-course difference $3-5=2$ ). Especially the average values for comfortable to very comfortable (Likert $5-6$ ) increased greatly at both SU and GU (see table 3). The average student post-course comfort values with these five research related tasks was reported much higher for SU than GU students. Mdn post-course difference; SU $6-$ GU $5=$ SU +1 .

Course Contribution to Research Skills (table 4): The course impact and its contribution to several research-related skills and abilities were evaluated by the students after the course. Table 4 below shows that the RUN courses had a positive impact on several research skills and abilities. Unfortunately, only post-course data exists in table 4.

Table 4: Course contribution and impact on research-related skills and abilities. The values in the frequency table are based on a six-item graded Likert scale from (1) Did not contribute at all to (6) Contributed a lot.

\begin{tabular}{|c|c|c|c|c|c|c|c|c|c|c|}
\hline $\begin{array}{l}\text { Research } \\
\text { abilities and } \\
\text { skills }\end{array}$ & Univ. & \# Stud. & Not $1^{1}$ & 2 & 3 & 4 & 5 & A lot 6 & $\begin{array}{l}\text { Median and } \\
\mathrm{IQR}^{2}\end{array}$ & $\begin{array}{l}\text { Post-course } \\
\text { difference } \\
\text { SU - GU }\end{array}$ \\
\hline \multirow{2}{*}{$\begin{array}{l}\text { Focusing on a } \\
\text { research topic }\end{array}$} & $\mathrm{SU}^{4}$ & $\mathrm{n}=21$ & $5 \%(1)$ & $5 \%(1)$ & $5 \%(1)$ & $10 \%(2)$ & $33 \% *(7)$ & $43 \%(9)$ & $5(4.5-6=1.5)$ & \multirow{2}{*}{$5-4=1$} \\
\hline & GU & $\mathrm{n}=31$ & $3 \%(1)$ & $16 \%(5)$ & $16 \%(5)$ & $39 \%$ & $19 \%(6)$ & $6 \%(2)$ & $4(3-5=2)$ & \\
\hline \multirow{2}{*}{$\begin{array}{l}\text { Conducting a } \\
\text { literature review }\end{array}$} & SU & $\mathrm{n}=21$ & $10 \%(2)$ & $5 \%(1)$ & $10 \%(2)$ & $19 \%(4)$ & $33 \%(7)$ & $24 \%(5)$ & $5(3.5-5.5=2)$ & \multirow{2}{*}{$5-4=1$} \\
\hline & GU & $\mathrm{n}=32$ & $16 \%(5)$ & $9 \%(3)$ & $22 \%(7)$ & $\mathbf{3 4 \%}(11)$ & $13 \%(4)$ & $6 \%(2)$ & $4(2-4=2)$ & \\
\hline \multirow{2}{*}{$\begin{array}{l}\text { Developing a } \\
\text { hypothesis }\end{array}$} & SU & $\mathrm{n}=21$ & $5 \%(1)$ & $5 \%(1)$ & $10 \%(2)$ & $19 \%(4)$ & $\mathbf{3 8 \%}(8)$ & $24 \%(5)$ & $5(4-5.5=1.5)$ & \multirow{2}{*}{$5-4=1$} \\
\hline & GU & $\mathrm{n}=31$ & $3 \%(1)$ & $13 \%(4)$ & $16 \%(5)$ & $\mathbf{4 2 \%}(13)$ & $19 \%(6)$ & $6 \%(2)$ & $4(3-5=2)$ & \\
\hline \multirow{2}{*}{$\begin{array}{l}\text { Designing an } \\
\text { experiment }\end{array}$} & SU & $\mathrm{n}=20$ & $0 \%(0)$ & $5 \%(1)$ & $0 \%(0)$ & $5 \%(1)$ & $35 \%(7)$ & $\mathbf{5 5 \%}(11)$ & $6(5-6=1)$ & \multirow{2}{*}{$6-4=2$} \\
\hline & GU & $\mathrm{n}=31$ & $0 \%(0)$ & $10 \%(3)$ & $6 \%(2)$ & $\mathbf{4 5 \%}(14)$ & $29 \%(9)$ & $10 \%(3)$ & $4(4-5=1)$ & \\
\hline \multirow{2}{*}{$\begin{array}{l}\text { Conducting the } \\
\text { experiment }\end{array}$} & SU & $\mathrm{n}=20$ & $0 \%(0)$ & $0 \%(0)$ & $0 \%(0)$ & $5 \%(1)$ & $20 \%(4)$ & $\mathbf{7 5 \%}(15)$ & $6(5.5-6=0.5)$ & \multirow{2}{*}{$6-5=1$} \\
\hline & GU & $\mathrm{n}=30$ & $3 \%(1)$ & $0 \%(0)$ & $13 \%(4)$ & $27 \%(8)$ & $\mathbf{3 7 \%}(11)$ & $20 \%(6)$ & $5(4-5=1)$ & \\
\hline \multirow{2}{*}{$\begin{array}{l}\text { Learning how to } \\
\text { use/interpret data }\end{array}$} & SU & $\mathrm{n}=21$ & $0 \%(0)$ & $0 \%(0)$ & $5 \%(1)$ & $14 \%(3)$ & $10 \%(2)$ & $\mathbf{7 1 \%}(15)$ & $6(5.5-6=0.5)$ & \multirow{2}{*}{$6-4=2$} \\
\hline & GU & $\mathrm{n}=31$ & $0 \%(0)$ & $13 \%(4)$ & $13 \%(4)$ & $\mathbf{3 2 \%}(10)$ & $29 \%(9)$ & $13 \%(4)$ & $4(3-5=2)$ & \\
\hline \multirow{2}{*}{$\begin{array}{l}\text { Analyzing } \\
\text { experimental } \\
\text { results }\end{array}$} & SU & $\mathrm{n}=20$ & $0 \%(0)$ & $0 \%(0)$ & $5 \%(1)$ & $10 \%(2)$ & $\mathbf{4 0 \%}(8)$ & $45 \%(9)$ & $5(5-6=1)$ & \multirow{2}{*}{$5-4=1$} \\
\hline & GU & $\mathrm{n}=31$ & $0 \%(0)$ & $13 \%(4)$ & $19 \%(6)$ & $\mathbf{4 2 \%}(13)$ & $19 \%(6)$ & $6 \%(2)$ & $4(3-5=2)$ & \\
\hline \multirow{2}{*}{$\begin{array}{l}\text { Presenting your } \\
\text { experiment }\end{array}$} & SU & $\mathrm{n}=21$ & $5 \%(1)$ & $5 \%(1)$ & $0 \%(0)$ & $14 \%(3)$ & $33 \%(7)$ & $43 \%(9)$ & $5(4.5-6=1.5)$ & \multirow{2}{*}{$5-4=1$} \\
\hline & GU & $\mathrm{n}=31$ & $6 \%(2)$ & $16 \%(5)$ & $19 \%(6)$ & $\mathbf{4 2 \%}(13)$ & $10 \%(3)$ & $6 \%(2)$ & $4(3-4=1)$ & \\
\hline \multirow{2}{*}{$\begin{array}{l}\text { Total average } \\
\text { values }\end{array}$} & SU & 20.6 & $3 \%(5)$ & $3 \%(5)$ & $4 \%(7)$ & $12 \%(20)$ & $\mathbf{3 0 \%}(50)$ & $47 \%(78)$ & $5(5-6=1)$ & \multirow{2}{*}{$5-4=1$} \\
\hline & GU & 31.0 & $4 \%(10)$ & $11 \%(28)$ & $16 \%(39)$ & 38\% (94) & $22 \%(54)$ & $9 \%(23)$ & $4(3-5=2)$ & \\
\hline
\end{tabular}

${ }^{1}$ Likert scale $=1$ (did not contribute at all) to 6 (contributed a lot). ${ }^{2}$ Median and interquartile range $\left(\mathrm{q}_{1}-\mathrm{q}_{3}=\mathrm{r}\right)$.

${ }^{3} \mathrm{SU}$ and GU post-course median difference. ${ }^{4}$ Light grey areas $=\mathrm{SU}$ values. $*$ Bolded $=$ Median Likert values.

Evaluation of Learning Impacts in Biomechanics: GU students felt positive about learning basic biomechanics during the first part of the course (i.e., to become LearnAble) before advancing to the project-based part (i.e., to become ConstructAble and somewhat ResearchAble). Compared to student attitudes in the previous RUN course, this result was an improvement. At GU, $67 \%$ passed the basic exam in biomechanics during RUN III. $12 \%$ more Journal of the Scholarship of Teaching and Learning, Vol. 16, No. 5, October 2016. josotl.indiana.edu 
students at GU passed the basic exam compared to the previous year. At Stanford, 95\% passed the exam in basic biomechanics during RUN III, which was a slight improvement of 3\% compared to the previous year. The exam tasks and the level of difficulties at SU and GU were similar to the previous year. However, the exam tasks at SU and GU differed, since the course contents and educational programs differed. In the previous course, in which students had to learn the basics of biomechanics while simultaneously completing their projects, learning new concepts and methods - as well as their tools and applications - proved too difficult to manage and thereby frustrated many students at both universities. SU and GU teachers and students generally agreed that students would most likely perform slightly better on a traditional written examination in a more traditional course. However, nearly all teachers and students at both universities agreed that allowing students to develop real-world problem-solving competences in an authentic, complex, professional environment was more valuable when compared to gaining slightly better basic biomechanical knowledge, which might be learned in a traditional course.

Evaluation of Participant Satisfaction: Nearly all teachers and students at both SU and GU positively evaluated the course design and its working modes and methods, and evaluations generally showed definitively more positive results than those regarding the previous project (Annerstedt et al., 2010; Castejon \& Sonesson, 2008). By contrast, during the last project year, SU and GU teachers and RUN project members also reported very few organizational and communication problems.

\section{Discussion}

Although traditional learning styles continue to dominate in higher education, their shortcomings have sparked a growing professional awareness about the need to explore alternative strategies for teaching and learning (NRC, 2003; AAAS, 2011; Sursock, 2015). Educational methods should focus more on active learning that motivates undergraduate students to become lifelong learners and stimulates their interest in science (Bologna, 2009). Recent educational research in life science underlines the need for early exposure to authentic lab research in courses at the undergraduate level (NRC, 2003; AAAS, 2011; Spell et al., 2014). The present study is important because of its innovative use of a blended, deep learning approach that focused on information-seeking processes and problem-based learning by using genuine, team-based research projects in exercise biomechanics courses. It also made use of cross-cultural multidisciplinary collaboration, ICT-battery use, and self-assessment methods. The results indicate that the RUN courses had a great impact on student interest and confidence in conducting lab tasks and authentic research. The results of this case study support recommendations for a shift towards the increased use of more authentic research-based courses in undergraduate study. The RUN project adds to a discernible and increasing body of evidence that research-based courses impact early undergraduate student interest in sciences and the development of authentic research-related skills and abilities, in contrast to traditional courses that often include "cookbook" labs.

It is important to be aware that this case study does have several limitations. First, this teaching style, complete with all its methods, tools, and approaches, was only fully tested twice. It will take more time and additional research to validate this complex concept and ensure its sustainability. Second, the participant sample was relatively small and the study was limited solely to an exercise biomechanics course. More students must be involved and the concept 
should be tested in additional areas of study. Third, the two student samples were not entirely comparable. SU students elected to take the course, but the GU students were required to take the RUN course as a part of their "educational package" to become teachers. The students who voluntarily elected to take the course were most likely more dedicated and motivated to learn. A difference in motivation could prove to be a compounding variable which makes it difficult to compare the SU and GU students in terms of satisfaction with the course and student mastery of learning outcomes. Additionally, the SU students were part of the Human Biology program and the GU students were studying to become physical education teachers. The human biology program includes more theory, more coursework in natural science, and generally more practice with scientific methods. Many of these students are pursuing careers in science or medicine. Indeed, during the RUN III course in 2008, the course director at SU reported that approximately one third of the human biology students at SU would enter medical school after their degree at the human biology program. The teacher program at GU includes coursework in didactics (physical activities in various sports arenas and settings) and social sciences. In 2008, just one third of the teacher program at GU involved study in natural science courses. It is quite natural that the SU students rated their research background and their level of comfort in research practices higher than the GU students, since they had more pre-course research experience and confidence in conducting research (tables 3 and 4).

A major limitation in this study was that the objective learning impact of the RUN course, as measured by course examinations over basic biomechanics, could not be compared with previous, more traditional courses in biomechanics. One of the aims of this study was to discover if it is possible and more valuable to learn the essential basics ("hard facts") in biomechanics at the undergraduate level while simultaneously developing genuine researchrelated skills and abilities in the same course. Unfortunately, in this study, the course content and questions differed too much from previous years to make relevant comparisons. Experienced teachers and staff with previous traditional experience who participated in this project could only give subjective reflections on this matter. Few studies exist that include a matched control group.

Due to these shortcomings, future research should use larger, randomized, and more heterogeneous student samples and include matched control groups in order to more fully compare the effectiveness of the RUN course to more traditional courses as an objective measure of the learning outcomes between these two teaching and learning styles.

Nevertheless, the pre- and post-course results clearly show that the RUN courses at SU and GU had a very positive impact on student self-confidence in working on an authentic research task (table 3). However, the post-course increase of student self-confidence was similar between SU and GU (table 3). Other course results (post-course only) clearly indicate that the course contributed greatly to several evaluated research tasks at both universities (table 4). All of these tasks were rated higher at SU than at GU. The higher task-values are interesting, since the SU students already had high pre-course self-confidence with research tasks, which probably indicates that the SU course had a major impact on their development of research-related skills and abilities. However, the GU students had more team work experience and all enjoyed working in teams, they were older, and they had more life-experience, which might compensate for their lower science experience and self-confidence in working with research-related tasks. The RUN teachers and staff at both universities generally agreed that the scientific quality of student project work was relatively equal. SU and GU student competence of learning basic biomechanics and working with authentic research-projects in the field were relatively similar.

Journal of the Scholarship of Teaching and Learning, Vol. 16, No. 5, October 2016. josotl.indiana.edu 
Problem-based learning: The ethnographic results from this case study indicate that the pedagogical method that the RUN project group used for real-world problem solving, problembased learning (PBL), were evaluated positively, as in the previous project year (Annerstedt et al., 2010). In contrast to traditional teaching methods that usually focus on declarative knowledge (i.e., facts), problem-based learning (PBL) in this course seemed to facilitate active and self-directed learning, challenged the students to identify their own learning tasks, facilitated group learning, research, and communication skills, ensured knowledge of a specified subject domain, and helped students to transfer knowledge to novel situations. The positive effects of this study are in line with the results from similar PBL research studies, which suggest that a PBL method not only enhances student knowledge of the basic principles but also has the potential to develop students' self-directed lifelong learning skills, to increase students' ability to solve real-world problems, and to increase students' motivation for learning (Vernon and Blake, 1993; Strobel \& van Barneveld, 2009; Nendaz \& Tekian, 1999). Despite a wealth of evidence, learning in higher education is still often driven by facts and assessment (Kolkhorst et al., 2001; AAAS, 2011; Labov et al., 2009).

Another valuable experience of this project was implementing the "Bologna Process" and teaching generic, research-related skills via interdisciplinary team-based research projects in human biology courses during the first cycle of university studies. The RUN project group believes that a cumulative building of generic, research-related skills is important to foster during the first cycle of university studies, and that it is suitable to develop these skills in several other first-cycle courses, in contrast to more lecture-based traditional course models. Almost no studies on authentic research-based courses exist with traditional course modules as controls. Due to the limitations from this study, an important goal for future studies will be to compare the content-based learning outcomes in biomechanics from this course module with more traditional courses as controls.

It is, of course, a slow and demanding process to change an established educational culture at a university, as well as old-fashioned opinions about how to learn. Most people find change of any sort to be difficult to adapt to, and, consequently, when new forms of teaching and learning are introduced, it is important to clearly address the issue of how to implement change and to allow time to make the transition. The RUN project group believes that one key to a sustainable and fruitful move to human biology education for the future, based on international guidelines, is to continue to support innovative educational projects such as the RUN project (Wood, 2009). Successful parts of the RUN project must be allowed to have continuous support from educational leaders over time (allowance to run and improve the course) in order to bring about change and sustainability (Graham, 2013; Wood, 2009). Courses within the human biology program at SU and the physical education teacher program at GU served as a test platform for the RUN concept.

The RUN courses have continued to be taught in a similar way at SU and GU after the RUN project ended in 2008. Therefore, a goal is to further validate and implement some tools and methods into other courses in the field at SU and GU, as well as to courses in other fields that have shown interest, such as applied engineering, entrepreneurship, health promotion (Lindh \& Rydmark, 2010), and music and drama. The RUN project group aims to expand the international network and to export the RUN concept to similar biomechanics courses at other universities.

Journal of the Scholarship of Teaching and Learning, Vol. 16, No. 5, October 2016. josotl.indiana.edu 


\section{Conclusions and the Future of the RUN Project}

The most obvious and useful results in this study indicate that it seems possible to simultaneously learn the essential basics of biomechanics and develop research-able skills and abilities. Collaboration among faculty and experts also promoted increased interest and awareness about the importance of testing new teaching and learning strategies. External funding is necessary to build up and evaluate this type of complex pedagogical joint course concept. The financial effort required to maintain the class itself is, at this time, beyond the scope of funding for either university. Elements of the project, such as real-world interdisciplinary problem solving in team-based research projects, joint virtual laboratories, and the use of web video to communicate with tutors and international experts has continued as components of the courses, and has been taught separately at each institution (to a lesser extent within normal course budgets). The enrollment numbers for both courses have been high enough to support the continued integrative approach towards biomechanics originally espoused by the WGLN grant. Plans are to continue to share results of the study in journals of higher education in order to encourage further collaboration and cooperation among various interested partners.

\section{Acknowledgement}

This project was funded by the Wallenberg Global Learning Network at Stanford University, 2005-08. The RUN project is still in progress, entitled Global RUN, and is funded by the Unit of Pedagogical Development and Interactive Learning at the University of Gothenburg and by the Vice Chancellor's Office at the University of Gothenburg, where a RUN course will be provided for second and third cycle students (2011- and 2015-). The student laboratory experiments were conducted in 2008 at the Human Performance Laboratory at the Division of Sports Medicine at Stanford University, and at the Lundberg Laboratory at the Sahlgrenska University Hospital. Many thanks to the following staff and students at SU and GU that have contributed to the RUN-project and made it possible (authors excluded): SU WGLN chair Prof. Craig Heller, GU former Dean Prof. Mikael Alexandersson. RUN-project manager: SU Dr. Cammy Huang DeVoss. Project investigator and course director: SU Daniel Garza $\dagger$. RUN teachers: SU Gannon Sungar, GU Dr Roy Tranberg, GU Dr Roland Zügner. Expert lecturers and consultants: SU Prof. Scott Delp, GU Prof. Jon Karlsson, University of Queensland Prof. Andrew Cresswell, Mid Sweden University Prof. Hans-Christer Holmberg, GU Dr. Lennart Gullstrand. SU webquestionnaire development: Prof. Patricia Youngblood. Tutors and master students: SU Brice Rolston, Alex Schorch, Tyler Johnston; GU Camilla Bohlin, Linus Kocken, Mathias Castejon, Linda Sonesson. ICT-technicians: SU Bob Smith, GU Svante Eriksson. Self-assessment software production: GU Gunther Dippe, Daniel Goude, Mattias Georgsson. Qualisys AB (Sweden): Fredrik Müller (CEO), Patrik Almström. Declaration of interest: The authors report no conflicts of interest.

\section{References}

American Association for the Advancement of Science. (2011). Vision and change in undergraduate biology education: A call to action. Washington, DC. 
Anderson, W A; Banerjee, U; Drennan, C L; Elgin, S C R; Epstein, I R; Handelsman, J., \& Warner, I. M. (2011). Science education. Changing the culture of science education at research universities. Science (New York, N.Y.), 331(6014), 152 - 153. UC Irvine: 21233371.

From http://escholarship.org/uc/item/1p37m7xw

Annerstedt, C., Garza, D., Huang-DeVoss, C., Lindh, J., \& Rydmark, M. (2010). Research-able through Problem-Based Learning. Journal of the Scholarship of Teaching and Learning, 10(2), 107-127. From http://josotl.indiana.edu/article/view/1745

Ary, D., Jacobs, L. C., Sorensen, C. K., \& Walker, D. (2013). Introduction to research in education. Cengage Learning.

Baskens, P. (2011). Scientists fault universities as favoring research over teaching. The Chronicle of Higher Education, 13. From http://chronicle.com/article/Scientists-FaultUniversities/125944/

Benvenuto, M. (2002). Educational reform: Why the academy doesn't change. Thought \& Action, 18(1/2), 63-74.

From http://199.223.128.55/assets/img/PubThoughtAndAction/TAA_02_07.pdf

The Bologna Process 2020 - The European Higher Education Area (EHEA) in the new decade. (2009). Communiqué of the Conference of European Ministers Responsible for Higher Education, Leuven and Louvain-la-Neuve, Belgum. From http://media.ehea.info/file/2009_Leuven_Louvain-la-Neuve/06/1/Leuven_Louvain-laNeuve_Communique_April_2009_595061.pdf

Buck, L. B., Bretz, S. L., \& Towns, M. H. (2008). Characterizing the level of inquiry in the undergraduate laboratory. Journal of College Science Teaching, 38(1), 52-58.

Carifio, J., \& Perla, R. (2008). Resolving the 50-year debate around using and misusing Likert scales. Medical education, 42(12), 1150-1152. DOI: 10.1111/j.1365-2923.2008.03172.x

Castejon, M., \& Sonesson, L. (2008). Biomechanics and Human Performance (7,5 ECTS) - En utvärdering av en internationell kurs i projektet RUN III. (An ethnographic evaluation of the RUN III project and joint course). Master Thesis 2008. University of Gothenburg.

Caudill, L., Hill, A., Hoke, K., \& Lipan, O. (2010). Impact of interdisciplinary undergraduate research in mathematics and biology on the development of a new course integrating five STEM disciplines. CBE-Life Sciences Education, 9(3), 212-216. DOI: 10.1187/cbe.10-03-0020

Chang, L. (1994). A psychometric evaluation of 4-point and 6-point Likert-type scales in relation to reliability and validity. Applied psychological measurement, 18(3), 205-215. DOI: 10.1177/00131640021970989 
Duncan, M. J., \& Al-Nakeeb, Y. (2006). Using problem based learning in sports related courses: An overview of module development and student responses in an undergraduate Sports Studies module. Journal of Hospitality, Leisure, Sport and Tourism Education, 5(1), 50-57.

Garza, D., Besier, T., Johnston, T., Rolston, B., Schorsch, A., Matheson, G., Annerstedt, C., Lindh, J. \& Rydmark, M. (2007). Use of a Virtual Human Performance Laboratory to Improve Integration of Mathematics and Biology in Sports Science Curricula in Sweden and the United States. Studies in Health Technology and Informatics., 2007, 140-142.

Graham R. (2013). Achieving systemic change in engineering education. Chalmers Conference on Teaching and Learning. Key note speech. From http://www.chalmers.se/clc/SV/projekt-ochsatsningar/pedagogisk-konferens/program-2013

Hanauer, D. I., Jacobs-Sera, D., Pedulla, M. L., Cresawn, S. G., Hendrix, R. W., \& Hatfull, G. F. (2006). Teaching scientific inquiry. Science-New York then Washington-, 314(5807), 1880.

Heinze, A. and Procter, C. (2004). Reflections on the Use of Blended Learning. Education in a Changing Environment Conference Proceedings, University of Salford, Salford, Education Development Unit. From http://www.ece.salford.ac.uk/proceedings/papers/ah_04.rtf

Hultberg, J., Plos, K., Hendry, G. D., \& Kjellgren, K. I. (2008). Scaffolding students' transition to higher education: Parallel introductory courses for students and teachers. Journal of Further and Higher Education, 32(1), 47-57.

Jamieson, S. (2004). Likert scales: how to (ab) use them. Medical education, 38(12), 1217-1218. DOI: 10.1111/j.1365-2929.2004.02012.x

Kjellgren, K. I., Hendry, G., Hultberg, J., Plos, K., Rydmark, M., Tobin, G., \& Säljö, R. (2008). Learning to learn and learning to teach-introduction to studies in higher education. Medical teacher, 30(8), e239-e245. DOI: 10.1080/01421590802258896

Knowles, M. S. (1975). Self-directed learning. New York: association Press.

Kolkhorst, F. W., Mason, C. L., DiPasquale, D. M., Patterson, P., \& Buono, M. J. (2001). An inquiry-based learning model for an exercise physiology laboratory course. Advances in physiology education, 25(2), 45-50. From http://advan.physiology.org/content/25/2/45.long

Labov, J. B., Reid, A. H., \& Yamamoto, K. R. (2010). Integrated biology and undergraduate science education: a new biology education for the twenty-first century? CBE-Life Sciences Education, 9(1), 10-16. DOI: 10.1187/cbe.09-12-0092

Likert, R. (1932). A technique for the measurement of attitudes. Archives of psychology.

Lindh, J., \& Rydmark, M. (2010). Blended Learning in a Global Interdisciplinary Inquiry-Based Laboratory Course for Advanced Level University Students. Going Global 4 - The United Kingdom International Education Conference. Queen Elizabeth II Conference Centre, England.

Journal of the Scholarship of Teaching and Learning, Vol. 16, No. 5, October 2016. josotl.indiana.edu 
Lindh, J., \& Rydmark, M. (2010). Virtual Coaching for Health. (2010). Proceedings of the Vitalis Conference 2010 - National Meeting Place for IT in the Health Care Sector, Sweden. From https://www.researchgate.net/publication/274963352_Virtual_Coaching_for_Health

Myers, M. J., \& Burgess, A. B. (2003). Inquiry-based laboratory course improves students' ability to design experiments and interpret data. Advances in physiology education, 27(1), 26-33. DOI: 10.1152/advan.00028.2002

National Research Council (US) Committee on Undergraduate Biology Education to Prepare Research Scientists for the 21st Century. (2003). BIO2010: Transforming undergraduate education for future research biologists. National Academies Press (US).

Nendaz, M. R., \& Tekian, A. (1999). Assessment in problem-based learning medical schools: A literature review. Teaching and learning in medicine, 11(4), 232-243.

DOI: 10.1207/S15328015TLM110408

Rissing, S. W., \& Cogan, J. G. (2009). Can an inquiry approach improve college student learning in a teaching laboratory?. CBE-Life Sciences Education, 8(1), 55-61.

DOI: $10.1187 /$ cbe.08-05-0023

Spell, R. M., Guinan, J. A., Miller, K. R., \& Beck, C. W. (2014). Redefining authentic research experiences in introductory biology laboratories and barriers to their implementation. CBE-Life Sciences Education, 13(1), 102-110.

Stone, D. and Zheng G. (2014) "Learning Management Systems in a Changing Environment" In book: Handbook of Research on Education and Technology in a Changing Society, Chapter: 56, Publisher: IGI Global. DOI: 10.4018/978-1-4666-6046-5.ch056

Strobel, J., \& Van Barneveld, A. (2009). When is PBL more effective? A meta-synthesis of meta-analyses comparing PBL to conventional classrooms. Interdisciplinary Journal of Problem-based Learning, 3(1), 4. From http://dx.doi.org/10.7771/1541-5015.1046

Sullivan, G. M., \& Artino, A. R. (2013). Analyzing and Interpreting Data From Likert-Type Scales. Journal of Graduate Medical Education, 5(4), 541-542.

DOI: http://doi.org/10.4300/JGME-5-4-18

Sundberg, M. D., Armstrong, J. E., \& Wischusen, E. W. (2005). A reappraisal of the status of introductory biology laboratory education in US colleges \& universities. The American Biology Teacher, 67(9), 525-529.

Sundberg, M. D., \& Armstrong, J. E. (1993). The status of laboratory instruction for introductory biology in US universities. The American Biology Teacher, 55(3), 144-146.

Sursock, A. (2015). Trends 2015: Learning and teaching in European universities. Brussels: European University Association.

Journal of the Scholarship of Teaching and Learning, Vol. 16, No. 5, October 2016.

josotl.indiana.edu 
Taylor, S. J., Bogdan, R., \& DeVault, M. (2015). Introduction to qualitative research methods: A guidebook and resource. John Wiley \& Sons.

Vernon, D. T., \& Blake, R. L. (1993). Does problem-based learning work? A meta-analysis of evaluative research. Academic medicine, 68(7), 550-63.

Weaver, G. C., Russell, C. B., \& Wink, D. J. (2008). Inquiry-based and research-based laboratory pedagogies in undergraduate science. Nature chemical biology, 4(10), 577-580.

DOI: $10.1038 /$ nchembio1008-577

Wood, W. B. (2009). Innovations in teaching undergraduate biology and why we need them. Annual Review of Cell and Developmental, 25, 93-112.

DOI: 10.1146/annurev.cellbio.24.110707.175306 